\title{
Levinas and the Anticolonial
}

Patrick D. Anderson

Journal of French and Francophone Philosophy - Revue de la philosophie française et de langue française, Vol XXV, No 1 (2017) 150-181.

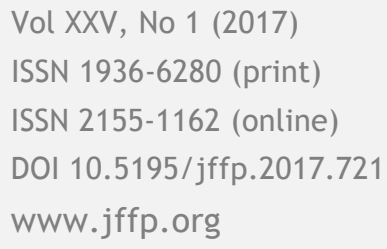

\section{(oc) EY-NO-ND}

This work is licensed under a Creative Commons Attribution-Noncommercial-No Derivative Works 3.0 United States License.

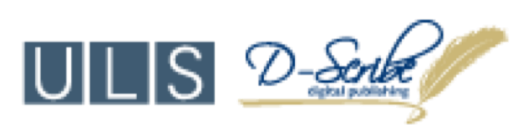

This journal is operated by the University Library System of the University of Pittsburgh as part of its D-Scribe Digital Publishing Program, and is co-sponsored by the University of Pittsburgh Press 


\title{
Levinas and the Anticolonial
}

\author{
Patrick D. Anderson
}

Texas A \& M University

The intellectual has been defined as the one who always misses the mark but who, at least, aims very far.

- Emmanuel Levinas ${ }^{1}$

Over the last two decades, the various attempts to "radicalize" Levinas have resulted in two interesting and important debates: one the one hand, there is the debate regarding the relationship between Levinas and colonialism and racism, and on the other hand, there is the debate regarding the relationship between Levinas and Judaism. Much to the detriment of both, these two conversations have largely been treated as separate issues, and when they have been brought together, the results have been either superficial or violent. For example, Robert Bernasconi and Robert Eaglestone have taken an identity politics approach, insisting that Levinas's Jewish identity is a source of strength for projects that put him into conversation with colonialism. ${ }^{2}$ On this view, Levinas's subaltern status provides enough distance between his work and Western imperialism that, with a few minor adjustments, his philosophy can be brought to bear on colonialism and racism without issue. But these arguments are philosophically uninteresting for two reasons: first, they assume that the identity of a philosopher results in some truth about his or her philosophy, or that one's subject position determines the nature of one's thought; and second, they require no serious engagement with the Jewish content of Levinas's philosophy.

If the identity politics approach is superficial, then what might be called the eliminativist approach is violent, resulting in a paradoxical deformation of Levinas that makes him virtually unrecognizable. In Levinas and the Postcolonial, John Drabinski attempts to "decolonize" Levinas by purging the debilitating Eurocentrism from his thought and universalizing the Levinasian ethical project. However, he also worries that the Jewish dimensions of Levinas's philosophy could keep it from "the sorts of geographical wanderings with which it ought to be engaged." ${ }^{3}$ Just as Eurocentrism threatens to incarcerate Levinas behind the walls of a dying

Journal of French and Francophone Philosophy | Revue de la philosophie française et de langue française Vol XXV, No 1 (2017) | www.jffp.org | DOI 10.5195/jffp.2017.721 
Europe, Drabinski believes that scholarship emphasizing or even celebrating Levinas's Judaism threatens to make him "ever more insular" and to result in a conservative disposition willing to confront neither Levinas's problematic Eurocentric statements nor his apparent "indifference to nation and race." ${ }^{4}$ Against this religious turn, Drabinski argues, "Levinas's work needs to be creatively reread across geographies - literal and figurative - in order to think more rigorously about the question of the Other as an ethical, cultural, and political question." ${ }^{5}$ Rather than a conservative "Loyalty to the text," ${ }^{\prime 6}$ Drabinski insists that "to uproot some of the foundations and habits of Levinas's own thought" is truly "what it means to radicalize Levinas." ${ }^{7}$ Thus, for Drabinski, Levinasian thinking needs to be used against Levinas himself in order to both universalize the ethical project and avoid the looming threat of a pernicious particularism, whether it is European, Jewish, or otherwise. But there is a paradox here. Drabinski's liberal rhetoric regarding diversity, difference, and identity implodes when turned back against his own project: he advances an ethical philosophy intended to respect differences of identity, but he predicates it upon the fundamental dismissal of Levinas's own "difference" - the Jewish content of his thought. Achieving the universalization of Levinas by eliminating his Eurocentrism is one thing, but to extricate the Jewish element of Levinas's thought in the name of universalism is to perform the Hegelian move of emptying him of the particular and filling him with the universal. Paradoxically, Drabinski's decolonized Levinas is a colonized Levinas.

Against the identity politics and eliminativist approaches, an anticolonial approach to understanding the relationship between Levinas, colonialism, and Judaism reveals that Levinasian contributions to understanding colonialism do not come from his ethical project but from his program for Jewish education. Oona Eisenstadt has noted that most scholars who discuss Levinas in the context of politics - whether they criticize him for a lack of politics or defend him from that criticism - completely ignore his Jewish writings, but an anticolonial approach bucks this trend. ${ }^{8}$ Unlike the identity politics of Bernasconi and Eaglestone, anticolonialism will insist that we take seriously the Jewish content of Levinas's thought, and unlike the eliminativism of Drabinski, anticolonialism will insist that it is only by taking that Jewish content seriously that Levinas tells us anything about colonialism. $^{9}$

But an anticolonial approach requires more than simply taking Levinas's Jewish writings seriously as political philosophy; it also requires us to reject the prevailing authority of postcolonial theory in favor of a more radical methodology. While "postcolonial" is notoriously difficult to define, many scholars understand postcolonialism as a radicalization of poststructuralism, postmodernism, and Marxism, a radicalization that both accounts for the indeterminacy of identity and "deterritorializes" the geographical borders that separate the superior and the subaltern. ${ }^{10}$ These 
notions of identity and geography frequently form the basis for postcolonial readings of Levinas. For example, Drabinski suggests that the openness, flexibility, and indeterminacy of the postmodern orientation of postcolonialism provide safeguards against the totalitarianism of metanarratives, rootedness, and borders, ${ }^{11}$ concluding that "Deterritorialized and deterritorializing practices decolonize the relation to the Other, transgressing the borders prescribed by the territorializing gaze, which then transforms political space into plurality, a morally gravitational Other, and differentiating work of solidarity." ${ }^{12}$ According to the postcolonial paradigm, only by acknowledging contingency and eradicating oppressive borders can we enter into a pluralistic space and cultivate the respect for otherness that global politics now demands.

This postcolonial language of identity and indeterminacy, of territory and transgression, is certainly alluring, even seductive, but from an anticolonial perspective there are genealogical and methodological reasons to be suspicious of it. Genealogically speaking, postcolonialism has derived nearly all of its central concepts from European philosophy, becoming a "convenient invention of Western intellectuals which reinscribes their power to define the world." ${ }^{13}$ From an anticolonial perspective, then, postcolonialism represents "the return of the Same in the guise of the Other. The language of race, class and nation is commuted into a universal crisis of 'identity' that makes these vexed issues more palatable within the academy." 14 Because it sublimates issues of history, political economy, death, and destruction into issues of identity, space, representation, and marginalization, and because it assumes an equal plane of existence upon which individuals are made unequal, "postcolonialism would not be a radicalization of postmodernism or Marxism, but a domestication of anticolonialism and anti-racism." ${ }^{15}$ And since postcolonialism focuses on the cultural and the linguistic at the expense of political economy, we might paraphrase Fredric Jameson and say: if postmodernism is the cultural logic of neoliberalism, then postcolonialism is the cultural logic of neocolonialism. ${ }^{16}$

Not only is postcolonialism genealogically problematic from an anticolonial perspective, it is also methodologically flawed because it views the colony through a lens of horizontal pluralism rather than a vertical dualistic ontology. Colonies are not created by establishing geographic borders along horizontal landscapes; they are created by establishing socioontological hierarchies along a vertical scaffolding. As John H. O'Dell reminds us, "In defining the colonial problem it is the role of institutional mechanisms of colonial domination which are decisive. Territory is merely the stage upon which these historically developed mechanisms of superexploitation are organized into a system of oppression." ${ }^{17}$ A society is a colony not because of its location nor because of its horizontal relation to other territories, but because of its structure and the vertical stratification of 
the people who inhabit it. While postcolonialism proceeds from an idealism that emphasizes the psychological dispositions and semiotic representations that privilege the Same and subordinate the Other, anticolonialism proceeds from a materialism that emphasizes the social structures and material oppressions that benefit the colonizer and dehumanize the colonized. Where postcolonialism sees a psychic antagonism between a superior and a subaltern, anticolonialism sees a material enmity between the human and the non-human.

Because space will not permit a full treatment of the anticolonial disposition of Levinas's Judaism, I will focus on demonstrating the limitation of the Levinasian ethical project to contribute to phenomenological or historical understandings of colonialism. In the first section, I argue against de-radicalizing, postcolonial interpretations of Frantz Fanon, arguably one of the most important and influential anticolonial theorists of the twentieth century, and emphasize the Manicheanism inherent in his criticism of colonialism. Fanon's dualistic understanding of the colonial world will be used to evaluate the adequacy of Levinas's phenomenology in describing the ontological structure of the colony and the historical experience of the colonized within it. ${ }^{18}$ In the second section, I will place Levinas's phenomenology of the ethical relation in conversation with Fanon's anticolonial phenomenology in order to raise heretofore-neglected issues about ethics, the face, and the Other and reveal the shortcomings of Levinasian descriptions of colonial life. In the third section, I will juxtapose Levinas's historical understanding the Holocaust with an anticolonial understanding of European racism and colonialism in order to demonstrate Levinas's inadequate conceptualization of racism, colonialism, and totalitarianism. Because my purpose is not to reject Levinas's thought in general but to encourage a new approach to his work, in the conclusion I will gesture toward the need for an anticolonial reading of Levinas's project for Jewish education. Levinas's incomplete understanding of the Holocaust as colonialism contributes to the inability of his phenomenology to describe the colony: the dividing line of colonial ontology, the zone of nonbeing, and the non-human status of the colonized. Nevertheless, Levinas's Jewish writings provide fertile ground for new scholarly conversations regarding anticolonial Judaism. ${ }^{19}$ 


\section{Constructing a Radical Methodology: Postcolonial or Anticolonial?}

By appealing, therefore, to our humanity - to our feelings of dignity, love and charity - it would be easy to prove and have acknowledged that the black man is equal to the white man. But that is not our purpose.

$$
\text { - Frantz Fanon }{ }^{20}
$$

Postcolonial theory's hegemonic position in relation to academic studies of colonialism has caused fundamental problems for the Levinas-colonialism debate. These problems stem from the tendency of the postcolonial paradigm to de-radicalize the anticolonial conception of colonial ontology, and such de-radicalization is most obvious in postcolonial renderings of Fanon's thought. Despite attempts to transform Fanon from an anticolonial to a postcolonial thinker and subsume him into the postcolonial canon, he relates to postcolonialism neither genealogically nor methodologically. Genealogically, he lived well before the advent of poststructuralism and postmodernism; methodologically, his dualistic anticolonialism stands in obvious contrast with, for example, Homi Bhabha's pluralistic interpretation of his work. ${ }^{21}$ It is not surprising that postcolonialism wants to claim him as their own, but "Postcolonial' Fanon," as Bryan Cheyette reminds us, "is no longer a revolutionary figure, theorizing violence and counterviolence and speaking for the oppressed, but is instead most concerned with questions of sexual and racial identity." 22 In fact, Fanon virtually anticipated such postcolonial renderings of his work, explicitly rejecting any attempt to understand the colony as a spatial arrangement of indeterminate identities. As he argues: "The colonial world is a Manichean world. The colonist is not content with physically limiting the space of the colonized, i.e., with the help of his agents of law and order. As if to illustrate the totalitarian nature of colonial exploitation, the colonist turns the colonized into a kind of quintessence of evil." ${ }^{23}$ We should thus resist postcolonial attempts to deradicalize Fanon; forcing him to conform to poststructuralist philosophies requires us to forget that Manichaeism is one of the central notions in Fanon's criticism of colonialism.

Fundamental to Fanon's dualistic analysis, then, is what we might call the dividing line of colonial ontology, which separates the colonizer and the colonized, or human beings and non-human non-beings. Taking the colonizer/colonized dualism as the fundamental structure of colonial social ontology, ${ }^{24}$ Fanon and other anticolonial theorists recognize that this dividing line separates the zone of being, in which the colonizers reside, from what Fanon calls the "zone of nonbeing," 25 in which the colonized reside. In other words, the colonizer and the colonized reside in different zones of social being: the colonizer resides in the zone of the human, and the colonized resides in the zone of the non-human. As María Lugones puts it,

Journal of French and Francophone Philosophy | Revue de la philosophie française et de langue française

Vol XXV, No 1 (2017) | http://www.jffp.org | DOI 10.5195/jffp.2017.721 
when colonization began, "the bourgeois white Europeans were civilized; they were fully human. The hierarchical dichotomy as a mark of the human also became a normative tool to damn the colonized. The behaviors of the colonized and their personalities / souls were judged as bestial and thus nongendered, promiscuous, grotesquely sexual, and sinful." ${ }^{26}$ The colonized individual is therefore not a hybrid or a subaltern but a non-being. Since colonial structures continue to persist today - through neocolonial policies abroad and through neoliberal capitalism domestically - the Manichean structure of traditional colonization has merely changed form, rather than ended. $^{27}$ Thus, it is not a question of how a superior relates to a subaltern, but how the human relates to the non-human.

Because the colonizer and the colonized reside in different zones of existence, philosophical anthropologies designed to describe the colonizer cannot account for the existential realities of the colonized. If ontology describes the zone of being and the life-world of the colonizer, then what I will call non-tology describes the zone of nonbeing and the life-world of the colonized. Despite continued efforts to transfer European categories from the ontological to the non-tological, Fanon continually warned against this tendency, insisting that the philosophies of the colonized cannot be rooted in European thought. In Black Skin/White Masks, for example, he says, "any ontology is made impossible in a colonized and acculturated society...there is an impurity or a flaw that prohibits any ontological explanation." ${ }^{28}$ In the concluding pages of The Wretched of the Earth, Fanon uses his final pen strokes to reiterate his warning, but now he adds that it is not only is it impossible, it is also undesirable:

For many of us the European model is the most elating. But we have seen...how misleading such an imitation can be. European achievements, European technologies and European lifestyles must stop tempting us and leading us astray. When I look for man in European lifestyles and technology I see a constant denial of man, an avalanche of murders. ${ }^{29}$

Fanon's dualistic description of colonial ontology and his insistence that the colonized should neither want to nor attempt to imitate European philosophy require us to question those who attempt to subsume him into the postcolonial canon. Unlike the postcolonial approach, therefore, which extends itinerant philosophies horizontally across diverse geographies, a Fanonian anticolonial approach imposes a barrier upon the vertical movement of philosophies from the ontological to the non-tological. And if anticolonial theory is correct about the structure of the colony, then no amount of geographical roaming will produce accurate descriptions of colonized peoples. ${ }^{30}$

In addition to the de-radicalization of colonial studies, the postcolonial paradigm has also led philosophers and literary critics to ask the wrong 
question regarding the relationship between Levinas's philosophy and the colony. They do not ask whether Levinas's phenomenology describes colonialism in any meaningful way; rather, they wonder to what extent his personal Eurocentrism is an impediment to the conversation they wish to have. ${ }^{31}$ While an anticolonial approach does not excuse Levinas's Eurocentrism, it does seek to avoid the moralistic disposition of most postcolonial analyses by asking a different question: To what extent does Levinas's phenomenology capture either the ontological structure of the colony or the experience of the colonized within it?

But before we can answer this question, we must return to the relationship between Levinas and the colony from an anticolonial outlook, which changes the set of relevant questions entirely. It is no longer about extracting the racism from his phenomenology and allowing it to roam horizontally across borderless geographies; it is about coming to a decision regarding where his phenomenology resides in relation to the dividing line of colonial ontology. If Levinas is strictly European, then the obvious answer is that his philosophy is a product of the ontological zone of the colonizer and can say nothing about the colonized. However, if we take Levinas's Judaism seriously, an interesting puzzle emerges, for in the French context, Jews were considered neither colonizer nor fully colonized. ${ }^{32}$ In The Colonizer and the Colonized, Albert Memmi, a Tunisian Jew writing during the period of decolonization in the French empire, observed that Jews are in neither the zone of being nor the zone of nonbeing; rather, they exist bestride the dividing line of colonial ontology. As he explains, Jews "live in a painful and constant ambiguity. Rejected by the colonizer, they share in part the physical conditions of the colonized and have a communion of interests with him; on the other hand, they reject the values of the colonized as belonging to a decayed world from which they eventually hope to escape." ${ }^{33}$ In the colonial context, some Jews, who "would, if they could, tear out their souls," consider themselves "candidates for assimilation." ${ }^{34}$ Memmi explains that many Jews "endeavor to resemble the colonizer in the frank hope that he may cease to consider them different from him. Hence their efforts to forget the past, to change collective habits, and their enthusiastic adoption of Western language, culture and customs." ${ }^{35}$ During decolonization, the desire for assimilation resulted in very material consequences, for many Jews fought on the side of the French against the Algerians. Many of Memmi's fellow Jews were even shocked when he dedicated himself to fight on the side of the colonized. Thus, the precarious existence of the Jews in the colony forced them to choose a side: attempt assimilation with the colonizer or fight with the colonized.

As a Jew in a colonial context, Levinas can be read as being confronted with these two options. On the one hand, Levinas could be read as an assimilationist, given his remarks regarding the universality of European culture: "When I speak of Europe, I think about the gathering of humanity.

Journal of French and Francophone Philosophy | Revue de la philosophie française et de langue française Vol XXV, No 1 (2017) | http://www.jffp.org | DOI 10.5195/jffp.2017.721 
Only in the European sense can the world be gathered together." ${ }^{36}$ On the other hand, Levinas could be read as an opponent of assimilation, given his opposition to late-nineteenth and early-twentieth century assimilation projects in France and Germany. ${ }^{37}$ Levinas was particularly concerned about the Wissenschaft des Judentum in Germany, which was led by assimilationist Jews seeking to achieve a "systematic study of Jewish texts following the norms of Western scholarship." ${ }^{38}$ Levinas confronts this movement in his writing, criticizing it for having "transformed the Holy Scriptures into pure documents." 39 Indeed, in "Antihumanism and Education," Levinas observes, "the Jew has not yet overcome all the complexes of a Marrano." 40 Thus unlike Fanon, who declares an explicit rejection of Europe and all its cultural and intellectual productions, Levinas seems to maintain both a fidelity to the colonizer (in his commitment to European philosophy) and a declaration of de-colonial autonomy (in his desire to protect Jewish culture and values). Plagued by the "painful and constant ambiguity" that according to Memmi defined Jewish existence in the colony, Levinas rejected the values of the colonized while resisting the complete absorption of Jews into European culture. However, we cannot simply choose one tendency or the other and then bend his thought to meet our needs. Because the fundamental issue at stake is not whether Levinas was personally Eurocentric or racist, but whether, from an anticolonial perspective, his phenomenology describes the colonial world and the experience of colonized peoples peoples, the test is not to see how Eurocentrism or racism affect his thought but to put his thought to the test and attempt to describe the colonial experience from the perspective of the colonized using his concepts. In the next two sections, we will analyze both Levinas's phenomenology and his historiography of suffering in order to determine their ability to illuminate the realties of colonialism from an anticolonial perspective.

\section{The Face of the Other and the Negrophobic Psyche}

Challenging the colonial world is not a rational confrontation of viewpoints. It is not a discourse of the universal, but the impassioned claim by the colonized that their world is fundamentally different.

- Frantz Fanon ${ }^{41}$

Scholars have acknowledged the importance of Fanon when it comes to colonialism studies, but they have not acknowledged the fundamental challenges that Fanon poses to his readers. For example, Drabinski suggests that "one could read the task of decolonizing Levinas and an ethics as a matter of deciding something of the legacy of Fanon's work." According to

Journal of French and Francophone Philosophy | Revue de la philosophie française et de langue française 
Drabinski, both Fanon and Levinas sought to replace a Hegelian understanding of intersubjectivity with something else, but unlike Fanon, who reached an "impasse," Levinas actually provided a vision of what that replacement might look like: the ethical phenomenology of the face. "Fanon's impasse is," he concludes, "the opening of a Levinasian thinking for postcolonial theory." ${ }^{42}$ Drabinski is correct that his work has implications for the legacy of Fanon, but they are not the implications he thinks they are. While Drabinski sees himself as completing Fanon's work, he actually ignores an important part of it, for he can see an "impasse" in Fanon only if he disregards Fanon's own answer: violence. ${ }^{43}$ Yet even if we agreed that Fanon's conclusions regarding violence are either wrong or undesirable, we would still have to show that Levinas's ethical project could indeed supplement Fanon's anticolonial thought without thereby betraying the rest of Fanon's critique of colonialism. Only by putting Levinas's phenomenology of ethical responsibility next to Fanon's psycho-existential account of colonial subjectivities is it possible to determine the extent to which Levinas's phenomenology can extend Fanon's anticolonial philosophy. $^{44}$

For Levinas, the experience of ethical responsibility is initiated by the encounter with the face of the other, the non-phenomenal invasion of the infinite beyond history into the finite field of ontology and politics. In Totality and Infinity, Levinas provides a phenomenological description of vision in which he explains that light illuminates a physical space before our eyes and reveals to us the plurality of objects in the world. "Light conditions," he says, "the relations between data; it makes possible the signification of objects that border one another." Light creates the conditions in which our vision can distinguish between objects, but there is a "connection between vision and touch, between representation and labor," from which "Vision moves into grasp." This grasp is both physical and epistemic: while the hand takes hold of an object in the world, controls its being, and determines its existence, the mind takes hold on an object by consigning it to a place within the field of epistemic representation and confining it within the parameters of our conception of it. Yet the ethical face eludes these manual and cognitive functions, for "Vision opens upon a perspective, upon a horizon, and describes a traversable distance, invites the hand to movement and to contact, and ensures them," but "Vision is not transcendence. It ascribes a signification by the relation it makes possible. It opens nothing that, beyond the same, would be absolutely other, that is, in itself." 45

If the ethical face of the other cannot be grasped by the eye, the hand, or the mind, Levinas is compelled to ask: "How does the epiphany as a face determine a relationship different from that which characterizes all our sensible experience?" ${ }^{46}$ His answer is that the face is a moment of the infinite, a manifestation of transcendence, which is identified by the 
manifestation of language or speech and which exceeds the finitude of ontological totality. In Levinas words, "The harsh law of war," the historical cycle of ontology, "breaks up not against an impotent subjectivism cut off from being, but against the infinite, more objective than objectivity." ${ }^{47}$ From the infinite, which exists outside totality and thus beyond and independent of ontology, language ruptures the ontological plane and radically interrupts the subject's phenomenological experience of the plane of being which light has illuminated. For Levinas, "Language is perhaps to be defined as the very power to break the continuity of being in history," since "discourse relates with what remains essentially transcendent." While the subject may see the physical face of the other, language interrupts that experience, for "Speech cuts across vision." ${ }^{48}$ Or as Levinas argues in "Ethics and Spirit," "Speaking and hearing become one rather than succeed one another. Speaking therefore institutes the moral relationship of equality and consequently recognizes justice. Even when one speaks to a slave, one speaks to an equal." ${ }^{49}$ After all, objects do not speak - people do. It is thus from the infinite that language and ethics, those metaphysical Siamese twins, manifest themselves within ontology.

In an effort to explicate the difference between totality and infinity, ontology and transcendence, Oona Eisenstadt writes, "Levinas draws a distinction between two structural levels of human experience, a preontological level and an ontological level." The first is "the level on which ethics passes" and the second is "the sphere of politics." ${ }^{50}$ This understanding is most helpful, but it excludes another important dimension in Levinas's thought; however, this overlooked dimension is not a third structural level in addition to the preontological and the ontological but a second zone within the ontological level. In the opening passages of Otherwise Than Being, Levinas explains that the preontological level, the transcendent site of infinity and ethical responsibility, is not non-being but otherwise than being. "Transcendence," he says, "is passing over to being's other, otherwise than being. Not to be otherwise, but otherwise than being." Transcendence cannot be defined by a shift of modalities or a change in substance. But there is more, and this is the crucial point: "And not to notbe; passing over here is not equivalent to dying. Being and not-being illuminate one another...Being's essence dominates not-being itself." ${ }^{51}$ Thus, if transcendence corresponds to what Eisenstadt calls the preontological level, then being and non-being both correspond to the ontological level, each one representing a particular zone of existence, neither of which captures the overwhelming presence of the infinite. ${ }^{52}$

While Levinas argues that every human individual has an ethical face from which the transcendence of infinity emanates, Fanon's analysis of colonial ontology problematizes the power of the ethical project to explain colonial relations. He does this through a two-step process in which he performs a "Psychoanalytic interpretation of the black myth" and a 
"Psychoanalytic interpretation of the black man's lived experience." ${ }^{53}$ Regarding the "Black myth," Fanon argues, those who reside in the zone of being - the ontological zone of the colonizer - cannot engage with those who reside in the zone of nonbeing - the non-tological zone of the colonized - in any sort of equal or honest way free of the (in this particular case) anti-Black racism that structures the very organization of the colonizer's psyche. As a Black man, Fanon explains, "I am overdetermined from the outside." Unlike the Jew, "I am a slave not to the 'idea' others have of me, but to my appearance." ${ }^{54}$ His appearance negates any subjectivity he might have (or wish to have) independent of his physical embodiment as a Black person, and he thus is reduced to corporeality, or as he puts it, "the black man is nothing but biological." ${ }^{55}$ As a body, the Black man becomes a pure object upon which whites can project any reprehensible interior feelings and desires through the process of "transitivity." "In Europe the black man has a function," Fanon explains: "to represent shameful feelings, base instincts, and the dark side of the soul." ${ }^{56}$ In a sexually repressed European culture, Black corporeality becomes Black genitality, for "As regards the black man everything in fact takes place at the genital level," according to whites. ${ }^{57}$ Through the process of Black "phobogenesis" whites react with anxiety, fear, and hatred to the Black individual, projecting all their sexual desires onto Black skin.

Translating Fanon's analysis into Levinasian terminology, "negrophobia" is one way in which the ethical face of the Other becomes obfuscated, distorted, or even eliminated, with the physical face overcoming the thrust of the infinite and transforming the Black body into an inert object to be "grasped." Yet two objections may be raised. First, one may point out that Levinas warned us of this very problem and advised against noticing "the color of [the Other's] eyes." Yes, but when we read that passage closely, Levinas admits that the true extent of the danger cannot be merely mitigated by casual awareness:

The best way of encountering the Other is not even to notice the color of his eyes! When one observes the color of the eyes one is not in the social relationship with the Other. The relation with the face can surely be dominated by perception, but what is specifically the face is what cannot be reduced to that. ${ }^{58}$

While the ethical relation with the face of the Other is not defined by the physical face, according to Levinas, the face can surely be dominated by perception. And Levinas does not seem to offer any solutions to this serious issue, which calls into question the power of Levinas's philosophy to prescribe strategies for the anticolonial struggle.

Second, one may insist that "Speech cuts across vision," and that Fanon would have to also explain how the anti-Black racist avoids the call of the Other, the Other's speech. Yet Fanon does this very thing in a chapter 
titled "The Black Man and Language." Here, Fanon would agree with Levinas on two points: first, humanity should not be reduced to animality; and second, speech or language is constitutive of all human relationships. In the colonial context, however, no amount of speaking will do the colonized any good. When a colonized subject speaks her native language, she is barbaric; when she speaks the colonialist language poorly, she is infantilized; and when she speaks the colonialist language well, she is dangerous. Just as phenotype overdetermines Black appearance, it also overdetermines Black speech, which means that for Fanon, there is a reversal of Levinas's claim that "Speech cuts across vision." In the colony, speech does not cut across vision - vision cuts across speech. The colonizer does not see the face and thus does not hear "You shall not kill." ${ }^{59}$ The colonizer only sees a nonbeing and thus only hears bar bar bar.

If Levinas's phenomenology has difficulty contributing to an "interpretation of the black myth," then it also has difficulty contributing to an "interpretation of the black man's lived experience." Fanon distinguishes between an ontogenic account that focuses on the formation of individuals as beings in a natural world and a sociogenic account that focuses on the formation of individuals as beings in a social world. For Fanon, any ontogenic analysis cannot account for the problems faced by colonized subjects - both because it takes no account of the social production of the inferior status of the colonized and because "the alienation of the black man is not an individual question." ${ }^{60}$ Because "there is a dialectical substitution when we switch from the psychology of the white man to that of the black man,"61 Fanon argues that only a sociogenic analysis will adequately describe the colony, and he makes a special effort to dismiss European thinkers - Hegel, Freud, Sartre...the list goes on - for remaining in an ontogenic mode. $^{62}$

The question becomes, then, whether Levinas offers an ontogenic or a sociogenic account of the individual. Certainly, his genetic account of the subject in Existence and Existents suggests an ontogenic approach, ${ }^{63}$ and the radical singularity of the face of the Other suggests the same. ${ }^{64}$ And even if Levinas may be able to make room for a sociogenic account within the ontological level, within politics, while nevertheless maintaining an ontogenic individualism within the preontological level, there is yet another barrier to making this move. In order to see this barrier, we must place Levinas's and Fanon's ontological schemas on top of each other.

Fanon's distinction between the ontological and the non-tological respectively correspond to the two dimensions of Levinas's ontological, namely, being and nonbeing. And we will grant for the moment that Levinas really does bring to the table the infinite, the otherwise than being lacking in Fanon. With this schema in mind, we must assess two different relationships: the one between being and otherwise than being and the one between nonbeing and otherwise than being. The relationship between being

Journal of French and Francophone Philosophy | Revue de la philosophie française et de langue française Vol XXV, No 1 (2017) | http://www.jffp.org | DOI 10.5195/jffp.2017.721 
and otherwise than being seems to be Levinas's entire project, the relation between ontology and transcendence, even if it is iterated in different forms over the course of his life. ${ }^{65}$ The relationship between nonbeing and otherwise than being is a different story, but we have to clarify what mode of nonbeing is at stake in the question. In Jewish Messianism and the History of Philosophy, Martin Kavka argues that nonbeing - what he calls by the Greek derivative "meontology" (to me on) - plays an important role in Levinas's work. But Levinas's notion of nonbeing contains a fundamental dimension of potentiality, or the "not-yet,"66 and it projects a certain individualistic overtone that focuses on the relationship between the individual and nonbeing. Kavka's explanation suggests that Levinas's has an ontogenic notion of nonbeing, which is very different from Fanon, who holds a sociogenic view of nonbeing as a zone of negation and depravity in which groups of people are consigned to live in a perpetual state if inferiorization. Fanon does recognize that, in some cases, "a genuine new departure can emerge" from nonbeing, but "In most cases, the black man cannot take advantage of this descent into a veritable hell." ${ }^{67}$ The basic dissimilarity between Levinas's and Fanon's notions of nonbeing - the meontological (pregnant with the not-yet) and the non-tological (defined by sterility) reveals that what is at stake is not merely the relationship between nonbeing and otherwise than being but the relationship between non-tology and otherwise than being. In this view, Levinas would have to be able to provide an account of how, if at all, the ethical face of the Other can emanate within the nontological, disrupting its routine just as it does the ontological. ${ }^{68}$

Turning to Levinas's notion of responsibility is an intuitive way to resolve the question regarding the relationship between nonbeing and otherwise than being, but this strategy faces serious difficulties. For Levinas, the desire to kill is inspired by anxiety provoked by the face, or as he puts it, "violence can only aim at a face." ${ }^{69}$ Eisenstadt has explained this well, saying, "Levinas understands full well that alterity arouses hostility," but "for him, this violence is not a disproof of responsibility, but in contradistinction, its very proof." ${ }^{70}$ However, in order to avoid circularity, we must remember what Levinas tells us about nonbeing: "to not-be" is "equivalent to dying." 71 Since the face is no longer present in death, there is no desire, no responsibility, and no obligation. There are two implications here. First, if the colonized are not, that is, if they reside in the zone of nonbeing, then the colonized subject is the living dead, a body with motion but a face without a face, a being that makes no ethical demands. Second, the colonized subjects who reside in the zone of nonbeing can be killed without the corresponding desire and thus with impunity. ${ }^{72}$ When we take Levinas's conceptions of responsibility and nonbeing together in the colonial context, the outcome is what Fanon anticipates - from the colonizer's point-of-view, he or she has no moral obligations to the colonized.

Finally, we must return to a temporary concession made above: that 
Levinas contributes a conception of transcendence to the colonial conversation that is lacking in Fanon. Most commenters assume this to be true without the proper analysis. For example, Anjali Prabhu argues that Fanon's conception of transcendence is liberatory in a political sense, while Levinas provides the necessary idea of transcendence as infinity. ${ }^{73}$ Yet this is false in such an ironic way that it is shocking that scholars have yet to investigate the philosophical importance of it. In Totality and Infinity, Levinas explains that "transcendence...is necessarily a transascendance," a term that he borrows from Jean Wahl's 1944 book Existence humaine et transcendence. ${ }^{74}$ Far from being a passing reference, Levinas's comment hints at a central feature of his thought; as Samuel Moyn confirms, "without Wahl, Levinas's formulation of his project would have been quite simply impossible."75 Levinas's gesture is twofold: not only is he acknowledging an intellectual debt to someone who was and would be a lifelong friend, but he also feels compelled to clarify exactly the type of transcendence he means. For Wahl, transcendence could go in two directions, or as he puts it, "Il n'y a pas seulement une transascendance, il y a une transdescendance." ${ }^{76}$ In Kierkegaardian fashion, one can transascend toward the divine, or one can transdescend toward "une force démoniaque." ${ }^{77}$ Levinas thus claims that the transcendence of infinity is always a movement toward the divine, a fact that seems to resonate with Levinas's project as a whole.

There is, however, a surprise waiting for those who wish to simply inject a Levinasian transcendence into Fanonian anticolonialism. In Black Skin/White Masks, Fanon explains that "Between the white man and me there is irremediably a relationship of transcendence," clarifying in a footnote, "In the sense meant by Jean Wahl, Existence humaine et transcendence." ${ }^{78}$ Uncanny - yet we must be sure to reveal all the implications of his meaning, for unlike Levinas, who limits his notion of transcendence to only the transascendant, Fanon does no such thing. This means that transcendence for Fanon likely carries both connotations. After all, the phobogenic object is always "endowed with evil intentions and with all the attributes of a malefic power," for "In Europe, evil is symbolized by the black man."79 And if transdescendence describes the movement toward the colonized, transascendence describes the movement toward the colonizer, for the white person will always be associated with purity, virtue, reason, and any other positive attribute one can imagine. And for the sake of completeness, it is notable that the transascendence/transdescendence distinction perfectly maps onto Fanon's explanation of interracial sexual desire: both the Black woman who desires white men and the Black man who desires white women do not actually desire their partners - they desire to transascend, to be white, to be human, to be divine.

It is safe to conclude that the assumptions made by Drabinski and others regarding the compatibility of Levinas and Fanon's philosophies are mistaken to the extent that we cannot merely supplement Fanon with 
Levinas's notion of the infinite, for Fanon has already inscribed it along the dividing line of colonial ontology. And that relation is for Fanon irremediable, not to be corrected. While Levinas may be able to describe the relation between two colonizers as a relation of transcendence and as ethically productive, his ontogenic description of the human cannot be brought to bear on the relation between the colonizer and the colonized. Because Drabinski believes that the colonizer and the colonized are "locked in mutual narcisim," ${ }^{80}$ he fails to account for the full range of analysis that must occur before he can claim that Levinas's thought fills in Fanon's impasse. At this stage in our investigation, it is tempting to respond to Levinasian phenomenological descriptions of the colony in the same way that Fanon responded to Dominique-Octave Mannoni's Prospero and Caliban: The Psychology of Colonization: "What we would like Monsieur Mannoni to do is explain for us the colonial situation - something, oddly enough, he forgot to do." 81

\section{Understanding Racism, Understanding Europe: Levinas vs. the Anti-Colonial}

[A] logical contradiction cannot judge a concrete event. The meaning of a logical contradiction that opposes two forms of ideas only shows up fully if we go back to their source, to intuition, to the original decision that makes them possible. It is in this spirit that we are going to set forth the following reflections.

- Emmanuel Levinas ${ }^{82}$

Having investigated the potential of Levinas's philosophy to contribute useful insights to understanding colonization, we now turn to evaluating his understanding of suffering and his philosophico-historical approach to both the Holocaust and colonialism. Paul Gilroy was one of the earliest theorists to comment on Levinas's understanding of the history of colonialism, and he set up somewhat of a challenge. While criticizing a series of European thinkers for acknowledging the horrors of the Holocaust but ignoring colonization, Gilroy says, "Emmanuel Levinas's remarks about the qualitative uniqueness of the Holocaust suggests that he suffers from a similar blind spot and that his understanding of the rational basis of these processes could not survive a serious encounter with the history of either slavery or colonial domination." ${ }^{83}$ Yet scholars have not taken up the task outlined by Gilroy, including Drabinski, for whom Gilroy's work "jolted me out of my dogmatic slumber." ${ }^{84}$ By comparing Levinas's understanding of the Holocaust with an anticolonial understanding of the Holocaust, it

Journal of French and Francophone Philosophy | Revue de la philosophie française et de langue française

Vol XXV, No 1 (2017) | http://www.jffp.org | DOI 10.5195/jffp.2017.721 
becomes possible to see why Gilroy is skeptical about Levinas's ability to account for the entire structure of European racism and militarism.

It is widely accepted that Levinas's "Reflections on the Philosophy of Hitlerism" established the dominant themes of his career, among which were his concerns about anti-Semitism, fascism, racism, and such related phenomena. But Levinas offers a particular understanding about the historical genesis of racism that influences his work. For Levinas, racism appeared on the landscape of European ideology sometime in the latenineteenth century when two important changes occurred. First, the dissatisfaction with liberalism initiated the transition from idealism to materialism, passing first through Marxism and resulting in pure biological immanence; through this process, the concept of and the hope for transcendence was eliminated as a possibility of human self-understanding. As Levinas describes, "Man no longer finds himself confronted by a world of ideas in which he can choose his own truth on the basis of a sovereign decision made by his free reason. He is already linked to certain number of these ideas, just as he is linked by birth to all those who are of his blood." ${ }^{85}$ Second, universality becomes decoupled from free dissemination and becomes paired with violence. "How is universality compatible with racism?" Levinas asks. "Universality must give way to the idea of expansion, for the expansion of a force presents a structure that is completely different from the propagation of an idea." ${ }^{86}$ When force replaces persuasion, imperialist "war and conquest" result. But for Levinas, racism and imperialism are not characteristic of European modernity as a whole; rather, they are historical accidents that developed at a specific time. Tina Chanter has noted that Levinas's 1934 examination contains a certain confusion about why Christians would acquiesce to racism and explains that his answer is force. ${ }^{87}$ Levinas seems to believe that Christianity and liberalism are opposed to racism, which contributes to his choice to not reject Europe outright.

While racism appears as an aberration of European philosophy rather than a permanent feature of it, anti-Semitism comes to represent all human suffering, not as an example but as a paradigm. For Levinas, "anti-Semitism is the archetype of all internment. Social aggression, itself, merely imitates this model. It shuts people away in a class, deprives them of expression and condemns them to being 'signifiers without a signified' and from there to violence and fighting." 88 The persecution of the Jews is not an example of another type of oppression or even an instance of a larger historical trend of European violence; it is the direct result the pure immanence of earlytwentieth-century materialism, and all other oppressions are iterations of anti-Semitism, which Levinas intimates by dedicating Otherwise than Being to the victims of the Holocaust and "the victims of the same hatred of the other man, the same anti-semitism." And while it may be tempting to attribute Levinas's understanding of the Holocaust to his experience of it - as a 
prisoner of war, as someone who lost many family members and friends Levinas takes himself to be making an objective claim about the structure of oppression rather than a subjective claim based on a visceral experience. In "Useless Suffering," he enumerates the "cruelties of our century," mentioning "the totalitarianisms of the right and left, Hitlerism and Stalinism, Hiroshima, the Gulag, and the genocides of Auschwitz and Cambodia," ${ }^{89}$ but he holds out the Holocaust as a somewhat objective paradigm:

Among these events the Holocaust of the Jewish people under the reign of Hitler seems to me the paradigm of gratuitous human suffering, in which evil appears in its diabolical horror. This is perhaps not a subjective feeling. The disproportion between suffering and every theodicy was shown at Auschwitz with glaring, obvious clarity. ${ }^{90}$

And one could see why scholars concerned with colonialism and slavery would object to Levinas's claim, since Levinas suggests that all other forms of suffering, all other oppressions, can somehow be met with a meaningful theodicy. Thus, Levinas does not merely privilege the Holocaust, he does so at the cost of invalidating, to a certain degree, myriad other experiences of subjugation and death. The apparent liminal nature of the Holocaust allows Levinas to place it at the center of his critique of suffering and oppression.

Anticolonial understandings of the Holocaust differ from Levinas's in several ways. To begin, for anticolonials, racism began much earlier than Levinas assumes, and many anticolonial thinkers have traced the ways in which racism has transformed over the centuries. Unlike Levinas, who sees racism as separate from Christianity and liberalism, Sylvia Wynter has described the process by which Christian justifications for believing in European superiority were replaced by scientific justifications for believing in European superiority. In the process, non-Christian peoples, especially Africans, became non-human beings. In Wynter's words,

In the new retotalization European man was transformed from Christian man to Western man; the other peoples of the earth were transformed into negroes and natives. The 'negro' was to be a particular form of the generic 'natives.' The European socio-cosmic vision of the world in which the social order paralleled the natural order was not discarded, but retained, transformed to serve the purpose now not of Christian theology, but of secular ideology. ${ }^{91}$

While Christian thought viewed Christendom as the most advanced form of civilization, the highest stage of human history, and the telos of providence, modern "secular ideology" turned to science in order to retain the connection between natural hierarchy and social hierarchy and identify Europe at the zenith of progress. While Levinas would have a difficult time explaining racism before the mid-nineteenth century (of which there is

Journal of French and Francophone Philosophy | Revue de la philosophie française et de langue française Vol XXV, No 1 (2017) | http://www.jffp.org | DOI 10.5195/jffp.2017.721 
plenty), ${ }^{92}$ anticolonial theory explains the historical continuities between the changing faces of racism.

Not only does racism have a much longer history than Levinas acknowledges, anticolonial theory also argues that the Holocaust is not an aberration of European culture; rather, it represents the truth of European culture. ${ }^{93}$ Already in 1920, W. E. B. Du Bois saw the first World War not as an historical accident but as a structural feature of Europe: "As we saw the dead dimly through rifts of battle-smoke and heard faintly the cursings and accusations of blood brothers, we darker men said: This is not Europe gone mad; this is not aberration nor insanity; this is Europe; this seeming Terrible is the real soul of white culture - back of all culture, - stripped and visible today." ${ }^{94} \mathrm{Du}$ Bois had come to expect war, terror, and death from Europe because he saw these practices as a part of its very existence. After World War II, he made a similar observation regarding the Holocaust: "There was no Nazi atrocity - concentration camps, wholesale maiming and murder, defilement of women or ghastly blasphemy of childhood - which Christian civilization or Europe had not long been practicing against colored folk in all parts of the world in the name of and for the defense of a Superior Race born to rule the world." ${ }^{95}$ For Du Bois, the Holocaust did not make its appearance in Europe in the 1930s; it appeared when the first slaves were taken from the coast of Africa, when the Spaniards descended upon the Aztecs with guns and disease, when the English began the genocide of the North American Natives, and when the Catholic church rounded up Jews for inquisition. This centuries old Holocaust of humanity manifested again against the Jews of Europe in a particularly horrific way. ${ }^{96}$

Some of the disagreement between Levinas and anticolonial theory may also come from their divergent perspectives on Adolf Hitler. In a 1989 interview, Levinas clarified his understanding of Martin Heidegger's relationship to the National Socialist Party. When the interviewer mentioned "Heidegger's commitment to the Nazis," Levinas cuts them off: "To Hitler." For Levinas, the defining characteristic of Heidegger's relationship to the Nazis was not adherence to an ideology but a commitment to Hitler the person. ${ }^{97}$ But in saying this, he commits himself to localizing evil in one individual (and perhaps those who, like Eichmann, willingly followed him) rather than recognizing the way in which Hitler was a product of a malicious culture. For example, it is a well-documented fact that eugenics movements existed in many Western nations, including the United States, whose practitioners and policies were very influential to the Third Reich. ${ }^{98}$ It is also known that the Britain practiced eugenics as part of their colonial strategy in Africa. ${ }^{99}$ Perhaps it is for these reasons that Marius Turda goes so far as to identify eugenics as "an expression of modernity." 100

Beyond these generalities of Western culture, Hitler himself claimed that the United States had greatly influenced his policies. In his book on the 
life of Hitler, John Toland explains how Hitler cited U.S. domestic policy and British colonial strategies as inspirations for the Holocaust:

Hitler's concept of concentrations camps as well as the practicality of genocide owed much, so he claimed, to his studies of English and United States history. He admired the camps for Boer prisoners in South Africa and for the Indians in the wild West; and often praised to his inner circle the efficacy of America's extermination by starvation and uneven combat - of the red savages who could not be tamed by captivity. ${ }^{101}$

In a relatively unknown sequel to Mein Kampf, Hitler also praised U.S. immigration policy as the reason for its growing national strength, since it established "specific racial requirements" for citizenship. ${ }^{102}$ Charles Mills has also demonstrated that Hitler saw himself as replicating the white supremacist practices of colonialism that define European modernity. ${ }^{103}$ The historical trends in eugenics and Hitler's personal testimonies regarding his influences problematize Levinas's fetishizing of Hitler and suggest that Black, Brown, and indigenous peoples were caught up in an historical tidal wave of brutality that eventually reached the interior of Europe and devastated the Jews. And if it seems counterintuitive to view the Holocaust as an example of the internal colonization of Europe, we must remember that a colony is a structure not a geography. Scholars have recognized the existence of "domestic colonies" on both the national level (especially the Black community in the U.S.) and the continental level (specifically the English colonization of Ireland). ${ }^{104}$

Perhaps the most famous expression of Nazism as the domestic colonization of Europe and of the general Hitlerian disposition of Europeans appears in Aimé Césaire's Discourse on Colonialism, in which he concludes, contra Levinas, that "Europe is indefensible." ${ }^{105}$ The utility of Hitler, according to Césaire, is that he so clearly reveals both the devastating truth of Europe and the hypocrisy of Europeans. On the one hand, Césaire argues that Hitler was the result of "a terrific boomerang effect" in which Europe's treatment of the world entered into a cycle of reflexive aggression in which its colonial practices were employed against its own people. This process both exposes Europe as "a sick civilization" and "makes it possible to see things on a large scale." On the other hand, Césaire calls out Europeans for opposing colonial practices used at home while looking the other way when it comes to the use of those practices abroad. What Europeans "cannot forgive Hitler for is not the crime in itself," he says, but "the crime against the white man." It will be left to the reader to decide if Césaire's criticism of European hypocrisy applies to Levinas, but given Levinas's apparent silence before 1933 and his subsequent understanding of the Holocaust, it is reasonable to think that it may. 
Ultimately, Césaire turns to the individual white European to expose the true location of Hitler: "it would be worth while to study clinically, in detail, the steps taken by Hitler and Hitlerism and to reveal to the very distinguished, very humanistic, very Christian bourgeois of the twentieth century that without his being aware of it, he has a Hitler inside him, that Hitler inhabits him, that Hitler is his demon." ${ }^{106}$ When juxtaposed with Levinas's fetishization of Hitler the individual, Césaire's damning critique of Western society metonymically represents the various challenges that an anticolonial understanding of the Holocaust presents. First, that racism is much older than the scientific racism of the late-nineteenth century. Second, that racism is constitutive of European modernity. And third, that each individual white Western subject, having been acculturated with the values of European modernity, threatens to carry on Europe's racial and colonial legacy. This is why, after the defeat of the Third Reich in 1945, Césaire could not accept the view that Nazism was finished. Because Blacks were still lynched in America, because Jews were still persecuted in Europe, and because Africans were still forced into labor in Africa, Césaire concluded: "we have certainly been lied to: Hitler is not dead." ${ }^{107}$

Despite the powerful arguments that an anticolonial paradigm presents for understanding the Holocaust as an instance of modern European colonization, this does not mean that there is no room for understanding either anti-Semitism or the Holocaust as qualitatively unique, even if they are not ontologically, epistemologically, or axiologically privileged. Regarding anti-Semitism, Fanon does say, "Colonial racism is no different from other racisms," but he does not mean they are qualitatively the same; he means that all racisms produce the same affect in him: "Anti-Semitism cuts me to the quick; I get upset; a frightful rage makes me anemic." In fact, he criticizes Sartre for equating anti-Semitism and anti-Black racism, subsuming them both under the category of the scapegoat. As Fanon writes, "Seeing only one type of black man and equating anti-Semitism with negrophobia seem to be the errors of analysis committed in [Sartre's] arguments." ${ }^{108}$ Likewise, Fanon suggests that the events of World War II generally and the Holocaust specifically require a rethinking of the problem, the nature, and the structure of colonialism. In "Racism and Culture," his 1956 address to First Congress of Negro Writers and Artists in Paris, Fanon states it as such:

The memory of Nazism, the common wretchedness of different men, the common enslavement of extensive social groups, the apparition of "European colonies," in other words the institution of a colonial system in the very heart of Europe, the growing awareness of workers in the colonizing and racist countries, the evolution of techniques, all this has deeply modified the problem and the manner of approaching it. ${ }^{109}$

Journal of French and Francophone Philosophy | Revue de la philosophie française et de langue française Vol XXV, No 1 (2017) | http://www.jffp.org | DOI 10.5195/jffp.2017.721 
While it might thus be tempting to accuse the anticolonial paradigm of diminishing the historical experience of Jewish suffering and oppression, Fanon reveals that it is possible to re-contextualize both anti-Semitism and the Holocaust within the logic of colonialism without thereby eliminating their particularities. ${ }^{110}$ In fact, quite the opposite seems to be true: understanding the Holocaust as an act of colonialism should be welcomed as it allows us to at least rethink - if not think anew - the problem of European modernity and its devastating misanthropic foundations. ${ }^{111}$

Returning to Gilroy's challenge, perhaps Levinas's understanding of the relationship between colonialism and the Holocaust is insufficient and cannot therefore contribute much to anticolonial work. Levinas conceived of racism only as biological racism and localized it to a few aberrations of European culture, causing him to miss racism's longer history and deeper roots in European culture. While a Levinasian understanding of the Holocaust threatens to relegate the horrors of colonialism to secondary place in the history of suffering, an anticolonial understanding of the Holocaust views it as an iteration of colonialism without thereby negating its uniqueness.

An anticolonial approach will see unavoidable shortcomings in Levinas's views on history, but it is important to remember that it is not for lack of experience that Levinas failed to theorize the zone of nonbeing. In a revealing passage, Levinas describes the process by which he was reduced to a non-human entity: "We were subhuman, a gang of apes. A small inner murmur, the strength and wretchedness of persecuted people, reminded us of our essence as thinking creatures, but we were no longer part of the world...We were beings entrapped in their species; despite all their vocabulary, beings without language." ${ }^{112}$ Levinas recognizes the process by which a human becomes a beast, a nonbeing, and becomes pure corporeality, devoid of reason and destined for death; despite the fact that he could indeed speak, he was without language and thus without a face in the eyes of his Others. Levinas's description resonates very closely with Fanon's account of the lived experience of the Black man discussed above, which suggests that Levinas himself, while in the camps, crossed the dividing line of colonial ontology and entered the zone of nonbeing. Through an inhuman relegation, he was cast into the non-tological, but unlike Fanon, who attempts to reconstruct the social structure - the colonial ontology - from within his existential crisis, Levinas struggled, as C. Wright Mills might put it, to connect his personal milieu with the social structure, to unite biography with history. ${ }^{113}$ It seems that there is an important lesson here: one's historical self-understanding influences one's philosophical reflections. Thus, it is not so much that Levinas's Eurocentrism must be purged; rather, it is that his understanding of European history needed to be improved.

Journal of French and Francophone Philosophy | Revue de la philosophie française et de langue française Vol XXV, No 1 (2017) | http://www.jffp.org | DOI 10.5195/jffp.2017.721 


\section{Conclusion: Toward an Anticolonial Judaism}

Prior to death there is always a last chance; this is what heroes seize, not death.

- Emmanuel Levinas ${ }^{114}$

Attempts to "radicalize" Levinas through decidedly non-radical paradigms, such as identity politics, postcolonialism, and empty universalisms, have resulted the decidedly non-radical moralizing, syncretism, and epistemic colonialism characteristic of these ideologies. Turning to anticolonial methodology, I argue that there are serious impediments to bringing Levinas's phenomenology into the colony, for his historical consciousness is incomplete and his phenomenology fails to describe the zone of nonbeing. Unlike Fanon and other anticolonial thinkers, who recognize that the zone of nonbeing is not a temporary aberration of an otherwise noble culture but a permanent component of Western ontology, Levinas believed that racism was merely the temporary neglect of the face of the Other. The question, therefore, is not "What can Levinas teach us about colonialism and racism?" but rather "What can anticolonial theory teach Levinas?" Both Levinas and contemporary scholars alike can learn a great deal from Fanon's insight that colonialism and racism are not isolated oversights regarding the humanity of the Other but the active dehumanization of the colonized.

Having revealed the inability of Levinas's phenomenology to adequately describe the colony, it may be tempting to disregard his work altogether. His experience of the zone of nonbeing, however, opens the door to another possible path, for the somewhat unreflective acceptance of Europe before 1933 was indeed shaken by Levinas's experience of the Holocaust. As Levinas says in his brief autobiographical essay published under the title "Signature," his work is "dominated by the presentiment and memory of the Nazi horror." ${ }^{115}$ Here, Levinas's experience of the "painful and constant ambiguity" of being a Jew in the colony comes forcefully into play. After being thrust into the zone of nonbeing, he condemned assimilationist practices and developed a project through which Jewish culture might be protected and regenerated. In "Antihumanism and Education," Levinas condemns Europe in a manner one might expect from Césaire, asking, "Is this the fragility of humanism in Western liberalism? Is it a basic inability to guarantee the privileges of humanity of which humanism had considered itself the repository?" ${ }^{116}$ In regard to the failings of Europe to live up to its purported values, Levinas proposes a project for Jewish education designed to protect Jews the world over from the dangerous tendency to assimilate. Once again, the question is not "How can we decolonize Levinas?" but rather "How did Levinas attempt to decolonize himself and his people?" In Nine Talmudic Readings, his answer is clear:

Journal of French and Francophone Philosophy | Revue de la philosophie française et de langue française Vol XXV, No 1 (2017) | http://www.jffp.org | DOI 10.5195/jffp.2017.721 
In the form of an autonomous political and cultural existence, Zionism makes possible a Western Jew, Jewish and Greek, everywhere. Given this, the translation "into Greek" of the wisdom of the Talmud is the essential task of the University of the Jewish State...The Diaspora, stuck in its living forces by Hitlerism, no longer has either the knowledge or the courage needed for the realization of such a project. ${ }^{117}$

He believes that Jews have a special contribution to make to humanity, a contribution that cannot be made if Jews continue on their abortive assimilationist path. Thus, Levinas's anticolonial consciousness resides not in his ethical project but in his program for Jewish education, which was born directly from his experience in the camps. One need look no further than Levinas's Zionist writings in order to see his anticolonial politics in action.

But Levinas's anticolonial Judaism should not be studied in isolation, for there is a rich history of Jewish resistance against Europe that might provide a context for understanding Levinas personally and anticolonial Judaism more generally. One famous anticolonial Jew, Albert Memmi, knew Fanon well, but Fanon worked with many anticolonial Jews during the Algerian Revolution. ${ }^{118}$ Furthermore, Cheyette reminds us of the disagreements between Jean Améry and Primo Levi regarding the proper response to Europe and the Holocaust. As he explains, "Améry, following Fanon, thought of violence as a form of negative transcendence, redeeming the oppressed" by ushering in a completely new humanism, "whereas Primo Levi, following Memmi and Arendt, rejected counterviolence in the name of the continuation of a radical tradition of European humanism.."119 We might view Levinas's project for Jewish education as falling somewhere on a spectrum between Améry and Levi. As Eisenstadt has said, if we want to know Levinas's politics, we must look to his Jewish writings. Now we can add: if we want to know what Levinas has to tell us about colonialism, we must turn to the same source.

\footnotetext{
1 Emmanuel Levinas, “Promised Land or Permitted Land," in Nine Talmudic Readings, trans. Annette Aronowitz (Bloomington, IN: Indiana University Press, 1990), 56.

${ }^{2}$ Bernasconi argues that the particularity of Levinas's ethnic allegiance is a source of resistance in the face of European cultural and racial hegemony. In a slightly different manner, Eaglestone argues that Levinas, as a Holocaust survivor, was always already a postcolonial subject and his philosophy always already a postcolonial project. Robert Bernasconi, "Who is my neighbor? Who is the Other? Questioning 'the Generosity of Western Thought,'" Ethics and Responsibility in the Phenomenological Tradition (Pittsburgh: Duquesne University, 1992), 1-31; Robert Eaglestone,
}

Journal of French and Francophone Philosophy | Revue de la philosophie française et de langue française Vol XXV, No 1 (2017) | http://www.jffp.org | DOI 10.5195/jffp.2017.721 
“Postcolonial Thought and Levinas's Double Vision," in Radicalizing Levinas, ed. Peter Atteron and Mathew Calarco (Albany: State University of New York Press, 2010): 57-68.

${ }^{3}$ John E. Drabinski, Levinas and the Postcolonial (Edinburgh: Edinburgh University Press, 2011), 3.

${ }^{4}$ Drabinski, Levinas and the Postcolonial, xvi.

${ }^{5}$ Drabinski, Levinas and the Postcolonial, 10.

${ }^{6}$ Drabinski, Levinas and the Postcolonial, xv. This is no doubt an uncited reference to Oona Ajzenstat's Driven Back to the Text: The Premodern Sources of Levinas's Postmodernism (Pittsburgh: Duquesne University Press, 2001).

7 John Drabinski, “Introduction: Levinas, Race, and Racism,” Levinas Studies: An Annual Review, Volume 7, ed. John Drabinski (Pittsburgh: Duquesne University Press, 2012), xix.

${ }^{8}$ Oona Eisenstadt, "The Problem of the Promise: Derrida on Levinas on the Cities of Refuge," Cross Currents 52.4 (2003), 474-482.

${ }^{9}$ There are at least two ways of taking Levinas's Judaism seriously, and either would be, at least at this initial stage, compatible with an anticolonial understanding of Levinas. We might conclude that there is either an indissoluble connection or an insurmountable tension between Levinas's Judaism and his most fundamental philosophical ideas. For now the important thing is that we must, if we want a Levinasian politics, start from his Jewish projects and not from his ethical project. For more on this conversation, see Claire Katz, Levinas and the Crisis of Humanism (Bloomington, IN: Indiana University Press, 2013); Ephraim Meir, “Judaism and Philosophy: Each Other's Other in Levinas," Modern Judaism 30.3 (2010): 348-362; Adriaan T. Peperzak, “Judaism and Philosophy in Levinas," International Journal for Philosophy of Religion 40.3 (1996):125145; Annette Aronowicz, "Jewish Education in the Thought of Emmanuel Levinas," Studies in Jewish Education 13 (2008/9): 97-129.

10 Regarding identity, poststructuralism and postmodernism provide the tools with which postcolonial thinking can avoid the identity essentialism of modernist European thought. Regarding geographies, postcolonial theory seeks to "deterritorialize" the colonial landscape and disobey imposed borders through a resistance to linguistic and cultural hegemony. See Bart Moore-Gilbert, Gareth Stanton, and Willy Maley, “Introduction,” in Postcolonial Criticism, ed. Bart Moore-Gilbert, Gareth Stanton, and Willy Maley (New York: Longman, 1997). Homi Bhabha, "Postcolonial Criticism," in Redrawing the Boundaries: The Transformation of English and American Literary Studies, ed. Stephen Greenblatt and Giles Gunn (New York: MLA, 1992), 441; Gilles Deleuze and Felix Guattari, Kafka: Toward a Minor Literature, trans. Dana Polan (Minneapolis, MN: University of Minnesota Press, 1986).

${ }^{11}$ Drabinski, Levinas and the Postcolonial, 109-113, 152-153, 170-178.

${ }^{12}$ Drabinski, Levinas and the Postcolonial, 181.

${ }^{13}$ Linda Tuhiwai Smith, Decolonizing Methodologies: Research and Indigenous Peoples (New York: Zed Books, 1999), 14.

${ }^{14}$ Moore-Gilbert, Stanton, and Maley, “Introduction,” Postcolonial Criticism, 3-4.

${ }^{15}$ Moore-Gilbert, Stanton, and Maley, “Introduction,” Postcolonial Criticism, 3-4.

${ }^{16}$ Graham Huggin, “The Neocolonialism of Postcolonialism: A Cautionary Note," Links and Letters 4 (1997): 19-24; and Jeannine Purdy, “Postcolonialism: The Emperor's New Clothes?,” Social \& Legal Studies 5.3 (1996): 405-426. 
${ }^{17}$ Qtd. in Robert L. Allen, Black Awakening in Capitalist America (Trenton, NJ: Africa World Press, 1992), 8.

${ }^{18}$ The basic assumption of my entire argument is that Fanon is right when he describes the colony. This assumption does not mean that I actually believe he is right about everything, though I do find myself agreeing with much of what he says. Rather, this assumption should be viewed as a hypothetical: for example, "If Fanon is right about the colony, then Levinas's phenomenology..." In this article, I am assuming the antecedent in order to analyze the consequent. There are many scholars that offer criticisms of Fanon's ideas in various forms, and certainly disagreeing with Fanon is neither unreasonable nor unexpected. However, there is a difference between disagreeing with Fanon and offering mistaken interpretations of Fanon. In this article, I hope to avoid the latter while maintaining space for future instances of the former.

${ }^{19}$ For an example of a similar approach from the decolonial tradition of Latin American philosophy, see Santiago Slabodsky, Decolonial Judaism: Triumphal Failures of Barbaric Thinking (New York: Palgrave Macmillan, 2014).

${ }^{20}$ Frantz Fanon, Black Skin/White Masks, trans. Richard Philcox (New York: Grove Press, 2008), 14.

${ }^{21}$ Homi K. Bhabha, "Remembering Fanon: Self, Psyche and the Colonial Condition - Forward to the 1986 Edition," in Frantz Fanon, Black Skin/White Masks, trans. Charles Lam Markmann (London: Pluto Press, 2008): xxi-xxxvii; Moore-Gilbert, Stanton, and Maley, "Introduction," Postcolonial Criticism.

${ }^{22}$ Bryan Cheyette, Diasporas of the Mind: Jewish and Postcolonial Writing and the Nightmare of History (New Haven, CT: Yale University Press, 2013), 44.

${ }^{23}$ Frantz Fanon, The Wretched of the Earth, trans. Richard Philcox (New York: Grove Press, 2004), 6.

${ }^{24}$ Albert Memmi, The Colonizer and the Colonized, trans. Howard Greenfield (London: Earthscan Publications Ltd., 2003); Amie Césaire, Discourse on Colonialism, trans. Joan Pinkham (New York: Monthly Review Press, 2001); Fanon, The Wretched of the Earth.

${ }^{25}$ Fanon, Black Skin/White Masks, xii.

${ }^{26}$ María Lugones “Toward a Decolonial Feminism,” Hypatia 25.4 (2010), 743.

${ }^{27}$ Allen, Black Awakening in Capitalist America; and Dylan Rodríguez, "The Black Presidential NonSlave: Genocide and the Present Tense of Racial Slavery," in Rethinking Obama (2011): 17-50; Kwame Nkrumah, Neo-Colonialism: The Last Stage of Imperialism (London: PANAF Books, 2004); Frantz Fanon, The Wretched of the Earth, 96-119; and Marissa Jackson, "Neo-Colonialism, Same Old Racism: A Critical Analysis of the United States' Shift toward Colorblindness as a Tool for the Protection of the American Colonial Empire and White Supremacy," Berkeley Journal of AfricanAmerican Law \& Policy 11.1 (2013), Article 10.

${ }^{28}$ Fanon, Black Skin/White Masks, 89-90.

${ }^{29}$ Fanon, The Wretched of the Earth, 236.

${ }^{30}$ We must reject the temptation to simply "extend" the categories of Western thought, which were meant to describe only the colonizer "humans," beyond the ontological boundary and "apply" them to the colonized. Many so-called progressive theories that attempt to "integrate" philosophy by allowing (or more accurately, forcing) non-Western, non-colonizer subjects to articulate their experiences and their communities through bourgeois categories ultimately commit what Sylvia Wynter calls "supraculturalism," which "mistakes or present local culture's 
representation-of the-human-as-a-natural organism as if it were the human-in-itself, mistakes the representation for the reality, the map for the territory." In the American academy today, European theory parades around as universal theory, a fantasy made possible through a combination of two intellectual shortcomings: first, the disavowal of the colonial history that produced such theory; and second, the mistaken notion that what was wrong with those theories was not that colonized people were excluded from them, but that the exclusion of colonized people was constitutive of those theories from the start. Sylvia Wynter, "'No Humans Involved': An Open Letter to My Colleagues," Forum N.H.I.: Knowledge for the $21^{\text {st }}$ Century 1.1 (1994), 49.

${ }^{31}$ Thus, the postcolonial debate in Levinas studies often settles into an opposition between what we might call a permissive postmodernist syncretism and an impermissive personalistic moralism.

On one end of the spectrum, Levinas's Eurocentric comments are simply ignored in favor of using the ethical project to call the West into question, make space for non-Western subjectivities and histories, and contribute "ethical" language for descriptions of colonial violence. [See Robert Young, White Mythologies: Writing History and the West (New York: Routledge, 1990); Homi K. Bhabha, The Location of Culture (London: Routledge, 1994); Andrew Gibson, Postmodernity, Ethics and the Novel: From Leavis to Levinas (New York: Routledge, 1999); Donald R. Wehrs, "Sartre's Legacy in Postcolonial Theory; or, Who's Afraid of Non-Western Historiography and Cultural Studies?" New Literary History 34 (2004), 772-773; Simone Drichel, "Regarding the Other: Postcolonial Violations and Ethical Resistance in Margaret Atwood's Bodily Harm," in Levinas and Narrative: Special Issue of Modern Fiction Studies (2008), 42-43. Drichel's argument is particularly concerning. Building from Wehrs's analysis of postcolonialism's "guilty conscience" about its relatively privileged position in Western academia relative to the position of the colonized peoples the world over, Drichel argues, "If to be postcolonial now means to have a 'guilty conscience,' then settler subjectivities in fact emerge as postcolonialism's most privileged example: no one else on the postcolonial spectrum is accustomed to negotiating a guilty conscience more than they are" (25). However, this view risks turning every white American, or at least the Founding Fathers, in to postcolonial subjects - hardly a desirable outcome. For more information regarding the Levinasian strand of postcolonial theory, see Jane Hiddleston, Understanding Postcolonialism (Montréal and Kingston: McGill-Queen's University Press, 2009).]

On the other end of the spectrum, scholars argue that Levinas's Eurocentrism - or rather his Euronarcissism - is an insurmountable impediment to bringing the ethical project to the colony. Most forcefully, Sonia Sikka argues that Levinas's Eurocentrism "does not constitute a hypocritical or inconsistent lapse on his part" but is rather "fundamental to his thought" ("How Not to Read the Other: 'All the Rest Can Be Translated,'” Philosophy Today 43.2 (1999), 199200). In addition, there are some moderates, such as Drabinski, who argue that syncretism is desirable and possible, but only once Levinas's Eurocentrism has been extracted from his thought. But as Rudi Visker suggests, the guiding concern imbedded in this conversational context is less the extent to which Levinas's thought resonates with the nature of colonial ontology and the experience of the colonized, and more the extent to which his emphasis on the recognition of Otherness resonates with the affective disposition of the scholars themselves ("Is Ethics Fundamental? Questioning Levinas on Responsibility," Continental Philosophy Review 36 (2003): 263-302).

${ }^{32}$ Louis Blond has argued that postcolonial criticisms of Levinas follow a distinct formula that finds him guilty by association. Europe is violence, phenomenology is European, Levinas is a phenomenologist - therefore, Levinas is complicit with violence. Blond is certainly correct that this line of association does not constitute a sufficient critique of Levinas, and here I take a different route in my criticism of Levinas's postcolonial critics: the aim is not to see if Levinas's 
thought is "European" or "Eurocentric" but to see if he offers a philosophical vocabulary that can be used to produce a compelling account of the colonial situation. See Louis Blond, “Levinas, Europe, and Others: The Postcolonial Challenge to Alterity," Journal of the British Society for Phenomenology 47.3 (2016): 260-275.

${ }^{33}$ Memmi, The Colonizer and the Colonized, 59-60.

${ }^{34}$ Memmi, The Colonizer and the Colonized, 166.

${ }^{35}$ Memmi, The Colonizer and the Colonized, 57, 59.

${ }^{36}$ Emmanuel Levinas, Is It Righteous to Be? Interviews With Emmanuel Levinas, ed. Jill Robbins (Stanford: Stanford University Press, 2001), 138.

${ }^{37}$ Derek J. Penslar, “Zionism, Colonialism and Postcolonialism," Journal of Israeli History: Politics, Society, Culture 20.2-3 (2001), 89, 94. See also, Michael Sohn, "Emmanuel Levinas and the New Science of Judaism,” Journal of Religious Ethics 41.4 (2013): 626-642.

${ }^{38}$ Penslar, "Zionism, Colonialism and Postcolonialism," 89.

39 Emmanuel Levinas, “Judaism," in Difficult Freedom: Essays on Judaism, trans. Seán Hand (Baltimore: The Johns Hopkins University Press, 1990), 25.

${ }^{40}$ Emmanuel Levinas, “Antihumanism and Education," in Difficult Freedom: Essays on Judaism, trans. Seán Hand (Baltimore: The Johns Hopkins University Press, 1990), 279.

${ }^{41}$ Fanon, The Wretched of the Earth, 6.

${ }^{42}$ Drabinski, Levinas and the Postcolonial, 13-15.

${ }^{43}$ Fanon's answer to the limitations of Hegelian dialectics and European colonization is not a mystery, for he spends much of his deathbed work The Wretched of the Earth explaining that violence is the solution: European colonizers must be killed. In fact, one need not wait until 1961 for Fanon to posit violence as the solution to colonization, for already in 1952, in Black Skin/White Masks, he said, "We would not be so naïve to as to believe that that the appeals for reason or respect for human dignity can change reality. For the Antillean working in the sugarcane plantations of Le Robert, to fight is the only solution. And he will undertake and carry out this struggle not as a result of a Marxist or idealist analysis but because quite simply he cannot conceive his life otherwise than as a kind of combat against exploitation, poverty, and hunger" (199). There are, of course, existing arguments - and good ones at that - for why we would want to reject the path of violence, but we should not dismiss it a priori.

${ }^{44}$ One other way to explore the relationship between Levinas and Fanon would be to determine if Levinas had ever read Fanon (or vice versa). I am not aware of any direct evidence that he had read Fanon, but they were both publishing in Espirit in the 1950s. Fanon had articles published in Espirit in 1951, 1952, and 1955, while Levinas published articles in the journal in 1956 and (twice) in 1960. Knowledge of Levinas's journal subscriptions and reading habits might reveal whether he had actually read Fanon's arguments in Espirit (let alone Fanon's books). If he had, he seems to have ignored them, perhaps because he thought they were either uninteresting or irrelevant.

45 Emmanuel Levinas, Totality and Infinity: An Essay on Exteriority, trans. Alphonso Lingis (Pittsburgh: Duquesne University Press, 1969), 191.

${ }^{46}$ Levinas, Totality and Infinity, 187.

${ }^{47}$ Levinas, Totality and Infinity, 25-26. 
${ }^{48}$ Levinas, Totality and Infinity, 195.

${ }^{49}$ Emmanuel Levinas, “Ethics and Spirit," in Difficult Freedom: Essays on Judaism, trans. Seán Hand (Baltimore: The Johns Hopkins University Press, 1990), 8.

${ }^{50}$ Oona Eisenstadt, "Eurocentrism and Colorblindness," Levinas Studies: An Annual Review, Volume 7, ed. John Drabinski (Pittsburgh: Duquesne University Press, 2012), 48.

${ }^{51}$ Emmanuel Levinas, Otherwise Than Being, or Beyond Essence, trans. Alphonso Lingis (Pittsburgh: Duquesne University Press, 1998), 3.

${ }^{52}$ Rudi Visker offers a similar argument. He says that in addition to our ontological bodies and our transcendental faces, our being and our otherwise than being, there is a third component called our "inscriptions." Inscriptions are a type of transcendence that does not speak. Each one of us has a multitude of inscriptions that our Other can experience, and these inscriptions make us unique just as, in a Levinasian way, our speech does; however, we cannot know our inscriptions - they are something that we can never know about ourselves. Because of this, Visker argues that there might be a non-ethical form of irresponsibility unaccounted for by Levinas's ethics. When we see the inscriptions of the other, we are reminded of our own inscriptions and our inability to access them. We become anxious, frustrated, and in response lash out at the other. Visker's argument is quite genius and has some merit; however, he universalizes his claims in a way that is incompatible with an anticolonial analysis. Like Husserl's analogical apperception, like Levinas's phenomenology of the face, Visker's theory of inscriptions assumes that all humans are taken to be humans, which is not the case in the colony. Visker criticizes Levinas for falling back on a privation argument: in Levinas's view, “any attempt on my part to ignore [my ethical responsibility] will be doomed to fail. No matter how I react to it, I will have done just that: react to it" (272). Likewise, Visker implies: when I react to the Other's inscriptions, I have still recognized them as human. Fanon's anticolonialism leads to two completely different conclusions: first, when the colonizer attacks/murders/mutilates the colonized, it is not because they are human but because they are non-human; and second, the anxiety provoked by the Other is not the same for both colonizer and colonized - the former is provoked by the psychogenic fear of the monster, while the latter is provoked by a very real fear of death at the hands of the white person. See Visker, "Is Ethics Fundamental?"

${ }^{53}$ Fanon, Black Skin/White Masks, 129.

${ }^{54}$ Fanon, Black Skin/White Masks, 95.

${ }^{55}$ Fanon, Black Skin/White Masks, 143.

${ }^{56}$ Fanon, Black Skin/White Masks, 167.

${ }^{57}$ Fanon, Black Skin/White Masks, 135.

${ }^{58}$ Emmanuel Levinas, Ethics and Infinity, trans. Richard A. Cohen (Pittsburgh: Duquesne University Press, 1985), 85-86. Emphasis added.

${ }^{59}$ Levinas, “Ethics and Spirit,” Difficult Freedom, 8.

${ }^{60}$ Fanon, Black Skin/White Masks, xv.

${ }^{61}$ Fanon, Black Skin/White Masks, 129.

${ }^{62}$ This aspect of Fanon's thought is so often overlooked it is worth going over in detail. In Black Skin/White Masks, Fanon rejects several famous psychoanalysists, stating that "Freud's discoveries are of no use to us whatsoever" (84) and that we must "free ourselves from the 
Adlerian cupping glass" (190) because "neither Freud nor Adler nor even the cosmic Jung took the black man into consideration in the course of his research" (130). Likewise, Fanon rejects, rather than reforms, Sartre's thought because "Jean-Paul Sartre forgets that the black man suffers in his body quite differently from the white man" (117). And Fanon follows up in a footnote: "Though Sartre's speculations on the existence of 'the Other' remain correct (insofar as, we may recall, Being and Nothingness describes an alienated consciousness), their application to a black consciousness proves fallacious because the white man is not 'the Other,' but also the master, whether real or imaginary" (117n.24). Finally, Fanon rejects Hegel, arguing that the master-slave dialectic of the colony "is basically different from the one described by Hegel. For Hegel there is reciprocity"; however, "The black slave wants to be like his master. Therefore he is less independent than the Hegelian slave" (195, see also 89-90). Because all of these European thinkers remain trapped within ontogenic hypotheses, Fanon insists that we recognize their inability to describe the life-world of the colonized.

${ }^{63}$ It is true that Levinas's account of the subject changes over the course of his life, but it is not immediately clear that he ever develops a robust sociogenic understanding of the subject. Because space does not permit such an investigation here, it is an important question that requires more consideration. I owe this point to Dwayne Tunstall.

${ }^{64}$ Nelson Maldonado-Torres, "Levinas's Hegemonic Identity Politics, Radical Philosophy, and the Unfinished Project of Decolonization," Levinas Studies: An Annual Review, Volume 7, ed. John Drabinski (Pittsburgh: Duquesne University Press, 2012), 84.

${ }^{65}$ Bettina Bergo has traced the shifts in Levinas's thought over the course of his life, and but these changes in his philosophy do not undermine my ultimate thesis that he never successfully recognized the zone of nonbeing. See Bettina Bergo, "Ontology, Transcendence, and Immanence in Emmanuel Levinas’ Philosophy," Research in Phenomenology 35.1 (2005):141-180.

${ }^{66}$ Martin Kavka, Jewish Messianism and the History of Philosophy (New York: Cambridge University Press, 2004), 131.

${ }^{67}$ Fanon, Black Skin/White Masks, xii.

${ }^{68}$ Without confusing matter too much, it might also be said that this relation is the relation between the non-tological and the non-ontological, as Levinas calls the transcendent infinity that is otherwise than being in "The Thinking of Being and the Question of the Other," in Of God Who Comes to Mind, trans. Bettina Bergo (Stanford: Stanford University Press, 1998), 119.

${ }^{69}$ Levinas, Totality and Infinity, 225.

${ }^{70}$ Eisenstadt, "Eurocentrism and Colorblindness," 53.

${ }^{71}$ Levinas, Otherwise than Being, 3.

72 This discussion of death is too large and too important to treat here in detail, for Levinas does provide many potentially helpful insights regarding death; yet, they would have to be either translated into sociogenic language or filtered so that only those statements compatible with sociogeny remained.

${ }^{73}$ Anjali Prabhu, "Eros in Infinity and Totality: A Reading of Levinas and Fanon," Levinas Studies: An Annual Review, Volume 7, ed. John Drabinski (Pittsburgh: Duquesne University Press, 2012), 127-146.

${ }^{74}$ Levinas, Totality and Infinity, 35. 
75 Samuel Moyn, Origins of the Other: Emmanuel Levinas between Revelation and Ethics (Ithaca, NY: Cornell University Press, 2005), 177.

${ }^{76}$ Jean Wahl, Existence humaine et transcendence (Neuchatel: Éditions de la Baconnière, 1944), 37.

${ }^{77}$ Wahl, Existence humaine et transcendence, 39.

${ }^{78}$ Fanon, Black Skin/White Masks, 117.

${ }^{79}$ Fanon, Black Skin/White Masks, 133, 165.

${ }^{80}$ Drabinski, Levinas and the Postcolonial, 15.

${ }^{81}$ Fanon, Black Skin/White Masks, 74.

82 Emmanuel Levinas, "Reflections on the Philosophy of Hitlerism," trans. Seán Hand, Critical Inquiry 17.1 (1990), 64.

${ }^{83}$ Paul Gilroy, The Black Atlantic: Modernity and Double Consciousness (Cambridge: Harvard University Press, 1993), 213.

84 John Drabinksi, “Levinas and After," jdrabinksi.com, Oct. 23, 2014: http://jdrabinski.com/levinas-and-after/

${ }^{85}$ Levinas, "Reflections on the Philosophy of Hitlerism," 70.

${ }^{86}$ Levinas, "Reflections on the Philosophy of Hitlerism," 70.

${ }^{87}$ Tina Chanter, "Neither Materialism nor Idealism: Levinas's Third Way," in Postmodernism and the Holocaust, ed. Alan Milchman and Alan Rosenberg (Atlanta: Rodopi, 1998), 142.

${ }^{88}$ Emmanuel Levinas, "The Name of a Dog, or Natural Rights," in Difficult Freedom: Essays on Judaism, trans. Seán Hand (Baltimore: The Johns Hopkins University Press, 1990), 153, emphasis added.

${ }^{89}$ Emmanuel Levinas, “Useless Suffering," Entre Nous: On Thinking-of-the-Other, trans. Michael B. Smith and Barbara Harshaw (New York: Columbia University Press, 1998), 94, 97.

${ }^{90}$ Levinas, “Useless Suffering,” 97, emphasis added.

${ }^{91}$ Sylvia Wynter, “Ethno or Socio Poetics,” Alcheringa: Ethnopoetics (1976), 82.

${ }^{92}$ For course, there are plenty of examples of racism before 1850 . Edmund Spenser and John Milton held reprehensible views about the Irish and Africans. Kant, Hume, Hegel, and Jefferson all, in their own ways represent some of the most racist philosophers in the Western canon. It would be interesting to see what Levinas would say about them, especially Kant, whom he admired.

${ }^{93}$ An anticolonial understanding of the Holocaust might be seen to represent what is known as a "realist" approach to Holocaust Studies, but Michael Rothberg has led the way in putting Du Bois's thought in conversation with Holocaust Studies in a way that undermines the realist/antirealist distinction. See Michael Rothberg, “W. E. B. Du Bois in Warsaw: Holocaust Memory and the Color Line, 1949-1952," The Yale Journal of Criticism 14.1 (2001): 169-189.

${ }^{94}$ W. E. B. Du Bois, Darkwater, in W. E. B. Du Bois: A Reader, ed. Eric J. Sundquist (New York: Oxford University Press, 1996), 502.

${ }^{95}$ W. E. B. Du Bois, The World and Africa and Color and Democracy, ed. Henry Louis Gates, Jr. (New York: Oxford University Press, 2007), 15. 
${ }^{96}$ In 1961, Fanon himself remarked that "Not so long ago, Nazism transformed the whole of Europe into a veritable colony." The Wretched of the Earth, 57.

${ }^{97}$ Levinas, Is It Righteous to Be?, 141

98 Stefan Kühl, The Nazi Connection: Eugenics, American Racism, and German National Socialism (New York: Oxford University Press, 1994); Steven Selden, Inheriting Shame: The Story of Eugrnics and Racism in America (New York: Teachers College Press, 1999); Nancy L. Gallagher, Breeding Better Vermonters: The Eugenics Project in the Green Mountain State (Hanover: University Press of New England, 1999); and André Pichot, The Pure Society: From Darwin to Hitler, trans. David Fernbach (New York: Verso, 2009); Mark Mazower, Hitler's Empire: How the Nazis Ruled Europe (New York: Penguin Press, 2009); James Q. Whitman, Hitler's American Model: The United States and the Making of Nazi Race Law (Princeton: Princeton University Press, 2017).

${ }^{99}$ Chloe Campbell, Race and Empire: Eugenics in Colonial Kenya (New York: Manchester University Press, 2007).

${ }^{100}$ Marius Turda, Modernism and Eugenics (New York: Palgrave MacMillan, 2010), 2.

101 John Toland, Adolf Hitler, Volume II (New York: Doubleday \& Company, Inc, 1976), 802.

${ }^{102}$ Here is the complete passage: "Compared to old Europe, which has lost an infinite amount of its best blood through war and emigration, the American nation appears as a young, racially select people...the American union itself, by theories of its own racial researchers, established specific criteria for immigration. By making an immigrant's ability to set foot on American soil dependent on specific racial requirements on the one hand as well as a certain level of physical health of the individual himself, the bleeding of Europe of its best people has become regulated in a manner that is almost bound by law." Adolf Hitler, Hitler's Second Book: The Unpublished Sequel to Mein Kampf, ed. Gerhard L. Weinberg, trans. Krista Smith (New York: Enigma Books, 2003), 109-110.

${ }^{103}$ Charles W. Mills, The Racial Contract (Ithaca, NY: Cornell University Press, 1997).

${ }^{104}$ Michael Hechter, Internal Colonialism: The Celtic Fringe in British National Development (New Brunswick, NJ: Transaction Publishers, 1999).

${ }^{105}$ Césaire, Discourse on Colonialism, 32.

${ }^{106}$ Césaire, Discourse on Colonialism, 36-38.

${ }^{107}$ Fanon quotes Césaire's statement from memory in Black Skin/White Masks, 70.

${ }^{108}$ Fanon, Black Skin/White Masks, 160-161.

${ }^{109}$ Frantz Fanon, "Racism and Culture," in Toward the African Revolution, trans. Haakon Chevalier (New York: Grove Press, 1967), 33.

${ }^{110}$ Du Bois expresses this same idea in his 1952 essay "The Negro and the Warsaw Ghetto." He explains: "I have seen something of human upheaval in this world: the scream and shots of a race riot in Atlanta; the marching of the Ku Klux Klan; the threat of courts and police; the neglect and destruction of human habitation; but nothing in my wildest imagination was equal to what I saw in Warsaw in 1949." And while this experience caused Du Bois to rethink the race problem globally, he nevertheless maintained that each version of racist violence and dehumanization were "all one crime against civilization." In W. E. B. Du Bois: A Reader, ed. Eric J. Sundquist (New York: Oxford University Press, 1996), 469-473. 
111 Some might argue that the work of Hannah Arendt offers a colonial understanding of the Holocaust without leaving the Jewish diaspora. As Michael Rothberg notes, Arendt's The Origins of Totalitarianism has been understood as resulting in "the colonial turn in Holocaust studies." However, Rothberg's comparison of Arendt with anticolonial thinkers such as Césaire and Du Bois leads him to conclude that, like Levinas, "Arendt proves unable to elude discourses of the human, the progressive, and the universal that remain complicit with the violence she is trying to explain. While Arendt remains at the limits of Eurocentrism, Césaire aims his polemic specifically against European self-understanding." Multidirectional Memory: Remembering the Holocaust in the Age of Decolonization (Stanford, CA: Stanford University Press, 2009), 24.

${ }^{112}$ Levinas, “The Name of a Dog," 153.

${ }^{113}$ C. Wright Mills, The Sociological Imagination (New York: Oxford University Press, 2000), 8-11.

114 Emmanuel Levinas, Time and the Other, trans. Richard A. Cohen (Pittsburgh: Duquesne University Press, 1987), 73.

115 Emmanuel Levinas, "Signature," in Difficult Freedom: Essays on Judaism, trans. Seán Hand (Baltimore: The Johns Hopkins University Press, 1990), 291.

${ }^{116}$ Emmanuel Levinas, “Antihumanism and Education,” 281.

117 Emmanuel Levinas, "Introduction," Nine Talmudic Readings, trans. Annette Aronowicz (Indianapolis, IN: Indiana University Press, 1990), 9-10.

${ }^{118}$ Lewis Gordon, What Fanon Said: A Philosophical Introduction to His Life and Thought (New York: Fordham University Press, 2015), 104-105.

${ }^{119}$ Cheyette, Diasporas of the Mind, 76. 